\title{
Infringement of the personal rights of a doctor and medical institution
}

\author{
Justyna Ożegalska-Trybalska
}

Intellectual Property Law Chair, Jagiellonian University, Cracow, Poland

Health and life constitute a special value for everyone. Therefore, parties involved in providing medical services are subject to exceptionally high expectations, and the activities of doctors and medical institutions are subject to social control. Such control is carried out with the participation of patients and journalists using mass media, particularly the Internet. Even though such control is allowed and freedom of speech and freedom of the press allow for public expression of opinions (including critical and negative ones), presenting one's position - even on important social issues - does not entitle one to infringe upon the personal rights of medical personnel and health care institutions. Meantime, criticizing and defaming doctors has become increasingly common in recent years due to the growing popularity of internet portals evaluating doctors, social media disseminating information, as well as the social tensions related to the overburdened health service and limited access to some health services due to the COVID-19 pandemic. Furthermore, patients exposed to stress about the health or hospital treatment are more likely to manifest their emontions by verbal aggression (insults or slanders) towards the medical personnel [1].

In the case of a threat to or infringement of personal rights, civil and criminal remedies are available to the doctor and the medical establishment, which protect against the negative consequences of an infringement of reputation or good name in the personal, professional and social sphere.

Key words: infringement of a doctor's personal rights, defamation, violation of good name, violation of the reputation of a medical institution

\section{The limits of protection of the personal rights of doctors and medical institutions}

In the case of the dissemination of insulting, untrue content or comments about a particular doctor, the limits of permitted criticism may be exceeded, and the doctor's personal rights violated (Article 24 in connection with Article 23 of the Civil Code of 23 April 1964, hereinafter the "Civil Code") [1].

Whether the negative opinions made public or disseminated are considered as a threat of infringement is determined by the assessment of the specific case and the accompanying circumstances. These are verified in the light of the general conditions for the application of these provisions, which include:

- identification of the personal good which has been infringed,

- individualization of a natural or legal person as a holder of a right,

- a threat or infringement of the right,

- establishing unlawfulness of interference into the sphere of protection of personal right.

\section{How to cite:}

Ożegalska-Trybalska J. Infringement of the personal rights of a doctor and medical institution. NOWOTWORY J Onco/ 2021; 71: 179-182. 
The most frequently violated personal rights are the good name and dignity of a doctor. Violation of this right may take place when a doctor is accused of improper conduct in carrying out their profession (e.g. lack of proper qualifications, malpractice, ignoring patients' rights, corruption, etc.). Such allegations may put him at risk of losing the trust necessary to carry out the profession of public trust changes in a behavior of patients or loss of them (e.g. the judgment of the Supreme Court of 29.10.1971, II CR 455/71).

If a medical institution (hospital, medical clinic, health center) is the subject of pejorative opinions or harassment, its reputation (good name) may be threatened or infringed (Article 43 in conjunction with Article 24 of the Civil Code), which shall be understood as patients' good opinion about its activity in the field of medical services. Infringement of this personal right of a legal person may consist in unjustified attributing to an institution of inappropriate, reprehensible operation accusing (e.g. low quality of services, negligence towards patients, abuses in providing medical services, bullying of employed personnel, etc.) negatively influencing its assessment by patients, including losing the trust necessary to perform its statutory tasks as a medical institution. The breach of reputation may also consist in untrue information being made public about irregularities in the work of hospital staff (in particular towards patients), which do not fall within the bounds of acceptable criticism as far they are not based on facts. As a rule, in such a case, a statement of the infringement of the personal interests of a medical institution does not, at the same time, constitute an infringement of the personal interests of its employees. However, there may be situations in which allegations against the employed personnel (doctor) may objectively affect the reputation of the institution and infringe its good name.

Apart from indicating the personal right that has been violated, it is also necessary to prove that the actions violating the personal right are not anonymous, which means that the questioned statements, opinions or negative comments shall explicitly refer to an individual person or institution.

The decisive factor for determining a violation of a personal right is not the subjective feeling of the doctor (institution) but the objective perception of specific behavior and the reaction it causes in public perception [2]. A required assessment is needed as regard the context of the allegedly infringing statements, their possible connotations, references, the situational context, the group of recipients, etc.

Demonstrating the severity of a threat or infringement may be difficult because the boundaries of acceptable criticism and the means used for this purpose are in case of doctors exercising a profession of public trust - significantly shifted. As confirmed by the court rulings, due to the specificity of their profession, a doctor who provides health services must take into account the fact that their activity may be openly criticized, and their personal rights (in particular their name) to the extent related to their profession are subject to weaker protection ( the judgment of the Supreme Court of 18 January 2013, IV CSK 270/12).

However, the presumption of unlawfulness makes it easier to enforce claims for the threatening or infringing of personal rights. It means that each infringement of personal property is treated as unlawful, unless there are special circumstances justifying interference in the sphere of personal rights. These include:

- acting as allowed by the applicable provisions of law,

- exercising one own's right,

- the wronged party's consent, and

- acting in defense of a justified interest (see the judgment of the Supreme Court of 4 June 2003, I CKN 480/01; the judgment of the Appeal Court in Kraków of 3 June 2020, I ACa 1315/19).

Freedom of speech and freedom of expression of opinions (Article 54 paragraph 1 of the Constitution of the Republic of Poland) and acting in defense of legitimate interests are usually invoked in disputes about the infringement of personal rights of doctors and medical institutions. However, one may exercise these rights as long as third parties' personal rights are not affected. Although patients and other persons have the right to express negative or unflattering opinions about a doctor, the limit of criticism is set by the doctor's right to protect their personal rights. Objective criticism may be regarded as socially useful, but it should not exceed the limits permitted by the law. When setting the limits, the court should balance the rights and interests of both parties, assuming that in comparison with the protection of personal rights, freedom of speech and the protection of personal rights are equally protected. On the one hand, the court may find that an evaluative or critical opinion or judgement leads to the infringement of personal rights if it is not based on an objective circumstances and facts and does not have the features of reliability and accuracy. That is because only the adequacy of the assessment to the described actual event repeals the unlawfulness of the utterance, even when it contains formulations that violate personal dignity or the good name of the doctor or the medical institution (judgment of the Supreme Court of 23.2.2017, I CSK 124/16). It is considered unlawful to disseminate false information (cf. judgments of the Supreme Court of 22.12.1997, II CKN 546/97 and 23.06.2004, VCK 538/03) or true information presented in a manipulated context (cf. the judgment of the Appeal Court in Białystok of 25.2.2016, I ACa 981/15). On the other hand, the use of even controversial forms of expression may fall within the permissible framework (as an action devoid of unlawfulness) because it concerns issues of major social importance (e.g. a doctor's opinion on the issue of transplantation, abortion, vaccine safety, etc.).

\section{Infringements of personal rights of doctors on the Internet and in press articles}

Special rules and circumstances relevant for the assessment of infringement of personal rights of doctors and medical in- 
stitutions concern the publication of negative comments and opinions on the Internet, on portals used to evaluate doctors, as well as press articles prepared by journalists - especially in sensationalist magazines.

Regarding the prevention of potential violations of third party rights, administrators are not obliged to check, monitor and censor the content posted by users (Article 15 of the Act on rendering electronic services of 18 July 2002) [3]. Instead, content verification for infringement may result from the specific rules of the portals and be carried out by moderators.

Once an infringement is noted, it is important to notify the administrator, who is obliged to react by removing the infringing content or preventing access to it. The administrator may also be a private person who has an open public profile on their website or a forum where Internet users can post comments. To assert claims in court proceedings, upon request and subject to the provisions of the data protection law, the administrator shall make available the user's data who infringed the personal interests by his/her entries. Suppose the administrator was aware of the existence of entries on his or her website that infringes someone else's personal rights or, in the case of being notified of their unlawful nature, does not react in the indicated manner. In that case, they are liable for infringement in a similar manner to the author of the entry (judgment of the Supreme Court's of 30.9.2016, I CSK 598/15).

The effectiveness and scope of claims for infringement of personal rights are influenced by the context of the individual case (e.g. negative statements on a portal dedicated to sharing opinions about doctors), the means of communication such as the Internet and the circle of people reached by the statement that infringes the personal rights. According to court rulings and practice, posting comments on an Internet forum constituting a public space justifies higher than average consent to a stronger, even exaggerated opinions and critical comments, characterized by a dose of exaggeration or even aggression. Moreover, portals posting opinions and comments on doctors also have greater permission to proceed with the name of doctors as their personal data, since such portals are considered one of the tools with which patients can exercise social control (the judgment of the Supreme Court of 20.1.2017, I CSK 99/16, the decision of the General Inspector of Personal Data of 23 December 2009, DOLiS/DEC-1323/09) [4].

The topic of medical services and doctors also appears in the mass media, including press articles describing medical errors or pathologies in the health service, sometimes using very strong forms of expression regarding specific persons or medical institutions. On these occasions, journalists exercise their freedom of expression and the right of citizens to reliable information, openness of public life and social control and criticism (Article 14 of the Constitution and Article 1 of the Press Law of 26 January 1984) [5]. However, freedom of the press does not justify the infringement of personal rights by providing information that is inconsistent with reality, unfoun- dedly damaging assessments (e.g. as to allegations of violating a patient's life or health, making the provision of services dependent on financial gain, etc.).

When using press materials, presenting facts, opinions, events and comments, a journalist shall exercise high care and diligence, particularly, when verifying the truthfulness of the obtained information or indicating its source (Article 12 of the Press Law). Statements of a reliable character (even if they contain unflattering statements) must be distinguished from criticism or negative assessment based on unsubstantiated facts or journalistic fiction. Suppose a publication manipulates facts, presents them in a selective or tendentious way, which may present a doctor or a medical institution in an dishonest way, personal rights such as a good name or image may be violated. This is the case if a journalist intentionally abuses editorial and language means, adding drama to the description and thereby strengthening the negative impact on the reader (the judgment of the Regional Court in Elbląg of 23.12.2013, I C 308/13).

\section{Claims of a doctor and medical entity in the case of infringement of personal rights}

Freedom of expression, which includes the right to criticize and express negative opinions to protect important social interests to which health care belongs, does not entitle one to make false accusations, slanderous, untrue or unreliable comments about doctors and medical service providers, which may constitute an infringement of their personal rights. The following means of protection are available for claiming such damages.

1. According to Article 24 of the Civil Code, a person whose personal right is endangered by someone else's action may demand that this action be abandoned unless it is lawful. In the case of an infringement, it is also possible to demand that the person who committed the infringement perform actions necessary to remove its effects to make a statement of appropriate content and in the appropriate form. The manner of remedying the infringement of personal rights should be selected in accordance with the type, intensity and scope of the infringement. If the infringement has been committed through an Internet publication or a particular newspaper, this is an appropriate medium to publish an apology or other statement. The provision mentioned above may constitute the basis for claims against natural persons (doctors or other medical personnel) and legal persons (hospitals, public and private clinics).

2. Irrespective of other measures required to eliminate the effects of the infringement of personal rights, in the case where the infringement is culpable, the entitled person may also demand pecuniary compensation or payment of an appropriate sum of money for the indicated social purpose (Article 448 of the Civil Code). In the situation where the violation of the good name or reputation has 
a real and direct impact on the loss of patients' trust and financial damage related to the loss of employment or income from providing medical services, it is possible to claim compensation on the general principles of the Civil Code (Article 24, paragraph 2, in connection with Article 415 of the Civil Code). In the case of a claim for compensation or damages, the doctor should demonstrate the extent of the harm or damage, respectively.

3. Some statements may lead to defamation (slander), which can be claimed as a criminal offense (art. $212 \S 1$ of the Act of 6 June 1997 - Penal Code) [6].

4. An independent tool that can be used in the case of an untrue or unreliable press publication infringing on a good name or reputation is to request the publication of free of charge, the subject-matter and factual correction of inaccurate or untrue press material within three working days of the receipt of the correction (Articles 31a and 32 of the Press Law).
Conflict of interest: none declared

\author{
Justyna Ożegalska-Trybalska \\ Jagiellonian University \\ Intellectual Property Law Chair \\ ul. Józefa 19 \\ 31-056 Kraków, Poland \\ e-mail:j.ozegalska-trybalska@uj.edu.pl
}

Received and accepted: 13 May 2021

\section{References}

1. O.J. 2020, sec. 1740, 2320

2. Ciosek A. Ochrona dóbr osobistych osób sprawujących funkcje publiczne. Acta Universitatis Wratislaviensis No 3161, Prawo, CCCVIII, Wrocław. 2009: 35

3. O.J. 2020 , sec. 344 .

4. Serwach M. Naruszenie dóbr osobistych lekarza na forum internetowym. Med Prakt. 2018; 1: 119-124.

5. O.J. 2018, sec. 1914.

6. O.J. 2020 , sec. 1444,1517 